\title{
Evaluation of Effectiveness of Nano Sensor (IITB) Based Irrigation System on Water Productivity and Yield of Maize (Zea mays)
}

\author{
C. Durga ${ }^{1}$, V. Ramulu ${ }^{2}$, M. Umadevi ${ }^{3}$ and K. Suresh ${ }^{4}$ \\ ${ }^{1}$ Agronomy, KAU, Thrissur, India \\ ${ }^{2}$ Office of the Director of Research, Administrative building, PJTSAU, \\ Rajendranagar, Hyderabad, India \\ ${ }^{3}$ Director of WTC \& Principal Scientist (SS\&AC), PJTSAU, \\ Rajendranagar, Hyderabad, India \\ ${ }^{4}$ O/o Controller of Examinations, PJTSAU, Rajendranagar, Hyderabad, India \\ *Corresponding author
}

\begin{abstract}
A B S T R A C T
The growing water demand has raised serious concern to the future of irrigated agriculture in many parts of the country. Therefore, the knowledge of crop water demand is an important practical consideration to improve the water productivity in irrigation practices. The traditional irrigation systems provide unnecessary irrigation to one part of a field while leading to a lack of irrigation in other parts. Changing environmental conditions and shortage of water have led to the need for a system which efficiently manages irrigation of fields. Based with this background a field experiment was conducted at Water Technology Centre, PJTSAU, Hyderabad (India) to study the effectiveness of sensor based irrigation system on water productivity and yield of maize. The experiment was laid out in a split plot design replicated thrice with twelve treatments using DHM-117 as a test variety of maize. The results revealed that the amount of total water applied under drip irrigation through nano sensor (IITB) based readings was $322 \mathrm{~mm}$ against the surface furrow irrigation of $494 \mathrm{~mm}$. Drip irrigation shown comparatively higher water productivity (1.96 $\mathrm{kg} \mathrm{m}^{-3}$ ) compared to surface furrow irrigation $\left(1.15 \mathrm{~kg} \mathrm{~m}^{-3}\right)$ and among the schedules higher water productivity (1.53) was associated with nano sensor (IITB). Simultaneously, nano sensor (IITB) based irrigation system recorded the highest grains per plant (184.13 $\mathrm{g})$, cob weight per plant (243.65 g) and grain yield $\left(7.05 \mathrm{t} \mathrm{ha}^{-1}\right)$ of maize.
\end{abstract}

\section{Keywords}

Nano sensor based irrigation, Water productivity, Drip irrigation, Maize and yield

Article Info

Accepted:

22 July 2020

Available Online:

10 August 2020

\section{Introduction}

Water plays a crucial role in photosynthesis and plant nutrition. Agriculture is the major user of fresh water, consumes $70 \%$ of the fresh water i.e. 1,500 billion $\mathrm{m}^{3}$ out of the 2,500 billion $\mathrm{m}^{3}$ of water that is being used each year (Shah and Das, 2012). One of the major problems in agriculture is non-optimal usage of water. It is estimated that $40 \%$ of the fresh-water used for agriculture in developing countries is lost, either by evaporation, spills, or absorption by the deeper layers of the soil, beyond the reach of plants roots (Shah and 
Das, 2012). The problem of agricultural water management is today widely recognized as a major challenge that is often linked with development issues. Irrigation scheduling is important parameter to increase yield of a crop. Saving water in the agriculture sector through efficient irrigation scheduling is one way to reduce water consumption. Irrigation scheduling helps the grower to know when to irrigate, how to irrigate and how much to irrigate. The most often used laboratory method for soil water content measurement is based on drying of the sample and measurement of the resulting mass decrease to find out the gravimetric soil moisture. Although this method leads to very accurate results and requires standard laboratory equipment (oven and precise scale), it is very time consuming, as it lasts 24 hours (Gardner et al 1986).

In today's commercial agriculture, technology plays an important role in different sectors of farm management. Various methods and tools have been developed to determine when and how much irrigation water needs to be applied, this is true particularly in soil moisture sensor technologies which have proven to be efficient in helping growers to manage irrigation (Mohamed et al., 2011). The agricultural sector faces the challenge to produce more food with less water by increasing crop water productivity (CWP) (Kijne et al., 2003). Same production with the limited water resources, or a higher production from the same water resources, helps to improve the crop water productivity. Sensor based irrigation scheduling offers an opportunity for improving water productivity. It helps to save the water by applying only when it is required. Agricultural sustainability is a great challenge to produce more from the limited resources to feed the growing population. Water consumption by irrigation is more than other activities. So the challenges of food security and water sustainability are closely linked. So, it is necessary to monitor the soil moisture in situ through sensor technologies as tools for irrigation scheduling for improving yield and to overcome the lacunas of gravimetric moisture measurement.

Reddy et al., (2002) observed higher sugar beet yield (95 $\mathrm{t} \mathrm{ha}^{-1}$ ) when irrigation was scheduled based on watermark sensors (gypsum block) along with saving of $18 \%$ water when compared to farmers practice. Chen et al., (2009) and Simon et al., (2013) concluded that the maize grain yield reduced with decreasing irrigation amounts and the maximum grain yield was obtained under fully irrigated treatment. Payero et al., (2008) recorded as low as $28 \%$ harvest index when plants are subjected to water stress after tasseling and maximum harvest index (61.77 $\%)$ was obtained with fully irrigated treatment. Karam et al., (2003) revealed that water plays an important role in partitioning of the dry matter and application of optimum quantity of water results in better $\mathrm{HI}$ in maize crop. Based on with this background a field experiment was conducted at Water Technology Centre, PJTSAU, Hyderabad (India) to study the effectiveness of sensor based irrigation system on water productivity and yield of maize.

\section{Materials and Methods}

The experiment was carried out at Water Technology Centre, College Farm, College of Agriculture, Professor Jayashankar Telangana State Agricultural University, Rajendranagar, Hyderabad. The farm is situated at $17^{\circ} 19^{\prime}$ 16.4" N latitude and $78^{\circ} \quad 24^{\prime} 43.7$ ' E longitude and at an altitude of $542.6 \mathrm{~m}$ above mean sea level. The experiment was laid out in a split plot design replicated thrice with twelve treatments using DHM-117 as a test variety of maize. Treatment combination are detailed in table 1 . 
Surface furrow irrigation was imposed by creating small parallel channels along the field length in the direction of predominant slope. Water is applied to the top end of furrow and flows down under influence of gravity. Measured amount of water was applied through gated pipe depending upon the treatment.

The drip system consisted of a head control unit (including non return valve, air release valve, vacuum breaker, disc filter, fertigation unit, throttle valve, pressure gauge and water meter); water carrier system (including PVC main pipeline, PVC sub main pipeline, control valve, flush valve and other fittings) and water distribution system (including 16 $\mathrm{mm}$ lateral line with inline emitters, grommet, start connecter, nipple and end cap).

The water source for irrigation was from an open well. The laterals of $16 \mathrm{~mm}$ diameter were laid at $1.2 \mathrm{~m}$ apart with spacing of $0.4 \mathrm{~m}$ distance between two inline emitters. The emitter discharge was $2.0 \mathrm{lph}$. Control valves were fixed separately to each treatment plot to facilitate controlling the water flow as per the treatments in the experiment.

In treatment S-1 to S-5, based on sensor triggered value irrigation was scheduled both in surface furrow irrigation and drip irrigation. The irrigation was rescheduled when the tension reached to 60-70 cbars in tensiometer, 40-50 centi bars in gypsum block, and when volumetric water content was registered as $20-25 \%$ in profile probe, gravimetric moisture content of $14-15 \%$ in nano sensor (IIT-B) and Red glow light indication in soil moisture indicator.

The number of cobs per plant, cob weight, grain weight per cob, number of grains per cob, grain yield, straw yield, harvest index and water productivity were recorded. The data obtained from the field experiment was analysed statistically by applying the techniques of analysis of variance (Gomez and Gomez, 1984). The F values for treatments were compared with the table values. If the effects were significant, critical differences at the $5 \%$ significance level were calculated for effecting comparison among the means. Data analytical package Web Agri Stat Package (WASP) ver 2.0 was used for data analysis.

\section{Results and Discussion}

The results of field evaluation of soil moisture sensors and irrigation methods on yield of rabi maize are detailed below.

\section{Number of cobs plant ${ }^{-1}$}

The number of cobs plant ${ }^{-1}$ in maize was not significantly affected by irrigation methods, as presented in Table 2. But under irrigation schedules it was found to be significant. The number of cobs plant ${ }^{-1}$ among the sub treatments ranged between 1.05 and 1.23. Number of cobs is more in drip irrigated plot compared to surface furrow irrigation. While in surface furrow method of irrigation, less number of cobs plant ${ }^{-1}$ recorded might be attributed to soil moisture stress experienced by the crop due to variations in amounts and frequency of irrigation water applied. Similar results were also reported by Kumar and Pandian (2010) and Sharan (2012). (Also mention about results of nano sensors)

\section{Cob weight $\left(\mathrm{g} \mathrm{plant}^{-1}\right)$}

The cob weight obtained was significantly high (244 $\mathrm{g} \mathrm{plant}^{-1}$ ) with drip irrigation method compared to surface furrow method of irrigation (196 g plant ${ }^{-1}$ ) (Table 2). High frequency of irrigation scheduled under drip irrigation resulted in high cob weight compared to low frequencies of irrigation under surface furrow irrigation (Prasad and 
Prasad, 1988). The cob weight of plant was significantly influenced by irrigation schedules and the highest cob weight $(243.65$ $\mathrm{g}$ plant $^{-1}$ ) was observed in nano sensors IITB, followed by gypsum block (239.20 $\left.\mathrm{g} \mathrm{plant}^{-1}\right)$ and differ significantly over rest of the irrigation schedules. The lowest cob weight (192.70 g plant $^{-1}$ ) was observed in irrigation scheduled by using tensiometer. Cob weight of maize was not significantly influenced by the interaction effect of irrigation methods and irrigation schedules.

\section{Grain weight $\left(\mathrm{g} \mathrm{plant}^{-1}\right)$}

Significantly higher grain weight (184.6 g plant $^{-1}$ ) obtained with drip irrigation methods compared to surface furrow method of irrigation $\left(143.7 \mathrm{~g} \mathrm{plant}^{-1}\right)$. Significantly higher grain weight $\left(193.57 \mathrm{~g}\right.$ plant $\left.^{-1}\right)$ was observed with nano sensors-IITB based irrigation scheduling followed by gypsum block (184.13 $\left.\mathrm{g} \mathrm{plant}^{-1}\right)$ and differ over rest of the schedules. Whereas the lowest grain weight (132.15 $\left.\mathrm{g} \mathrm{plant}^{-1}\right)$ was observed in irrigation scheduled by using tensiometer (Table 2). Corn grown under conditions of water deficit in sensitive stages causes least grain weight per year (Cakir 2004). These results support the view that water stress at different growth stages affects grain weight per cob to a greater or lesser degree depending on the stage (Bajwa et al., 1987; Roy and Tripathi, 1987). The per plant grain weight of maize was not significantly influenced by the interaction effect of irrigation methods and irrigation schedules.

\section{Number of grains per cob}

Significantly more number of grains per cob was noticed with drip irrigation method (485.00) compared to surface furrow method of irrigation (441.00) (Table 2). Yield components of maize like number of grains per cob, 100 grain weight were found higher with drip irrigation scheduled at 1.0 Epan compared to surface method (Salah et al., 2008; Asim et al., 2011 and Sharan, 2012). The increase in number of grains per cob might be due to lower bareness of the cobs under high irrigation frequency regimes during growth period. The reduction in bareness of the cobs at higher irrigation level might be due to better pollination and consequent to better filling of cobs due to optimum moisture availability (Aulakh et al., 2012). The number of grains per cob was not significantly influenced by the sensor based irrigation schedules and the highest number of grains per cob was observed by nano sensors IITB, followed by profile probe, gypsum block, soil moisture indicator, IW/CPE ratio. The lowest number of grains per cob was observed in irrigation scheduled by tensiometer. Yazar et al., (1999) reported that number of grains per plant is moisture stressdependent and concluded that number of grains per cob decrease is the primary effect of water deficit on corn grain yield. Setter $e t$ al., (2001) evaluated the processes of kernel setting under a 5 days water stress and shading at the pre-pollination and early postpollination stages, and determined that water deficit substantially increased ABA concentrations in all reproductive tissues of corn. They suggested that ABA may play a role in the loss of kernel set within apical regions of an ear in response to water deficit. The number of grains per cob of maize was not significantly influenced by the interaction effect of irrigation methods and irrigation schedules.

\section{Grain yield $\left(\mathrm{t} \mathrm{ha}^{-1}\right)$}

The grain yield of maize was significantly influenced by irrigation methods and irrigation schedules. Significantly higher grain yield $\left(6.30 \mathrm{t} \mathrm{ha}^{-1}\right)$ was obtained with drip irrigation compared to surface furrow irrigation plots $\left(5.68 \mathrm{t} \mathrm{ha}^{-1}\right)$ (Table 3). 
Table.1 Details of treatments

\begin{tabular}{|l|l|}
\hline Main treatments: $\mathbf{M}_{1}$ - Surface furrow irrigation and $\mathbf{M}_{2}$ - Drip irrigation \\
\hline $\begin{array}{l}\text { Sub treatments- } \\
\text { Sensor based irrigation schedules (S) }\end{array}$ & $\begin{array}{l}\text { Indicator value in the sensor to } \\
\text { trigger the irrigation }\end{array}$ \\
\hline $\mathbf{S}_{1}$-Tensiometers (irrometer) & $60-70$ cbars \\
\hline $\begin{array}{l}\mathbf{S}_{2} \text {-Granulated gypsum blocks (Water mark } \\
\text { sensors) }\end{array}$ & $40-50 \mathrm{cbars}$ \\
\hline $\mathbf{S}_{3}$-Profile probe (Delta-T) & $20-25 \%$ (moisture content volumetric) \\
\hline $\mathbf{S}_{4}$-Nano sensors (IITB) & $14-15 \%$ (moisture content gravimetric) \\
\hline $\mathbf{S}_{5}$-Soil moisture indicator (ICAR) & Red LED glow \\
\hline $\mathbf{S}_{6}$-IW/CPE ratio or Epan & 1.0 \\
\hline
\end{tabular}

Table.2 Effect of irrigation methods and irrigation schedules on number of cobs plant ${ }^{-1}$, number of grains per cob, cob weight and grain weight of maize during rabi 2017-18

\begin{tabular}{|c|c|c|c|c|}
\hline Treatment & $\begin{array}{l}\text { No. of } \\
\text { cobs } \\
\text { plant }^{-1}\end{array}$ & $\begin{array}{l}\text { No. of } \\
\text { grains per } \\
\text { cob }\end{array}$ & $\begin{array}{l}\text { Cob } \\
\text { weight } \\
\left(\text { g plant }^{-1}\right)\end{array}$ & $\begin{array}{l}\text { Grain } \\
\text { weight }(g \\
\left.\text { plant }^{-1}\right)\end{array}$ \\
\hline \multicolumn{5}{|l|}{ Main plots :Irrigation methods (M) } \\
\hline $\mathrm{M}_{1}$-Surface furrow irrigation & 1.16 & 441.0 & 196.0 & 143.70 \\
\hline $\mathrm{M}_{2}$-Drip irrigation & 1.19 & 485.0 & 244.0 & 184.60 \\
\hline $\mathrm{SEm} \pm$ & $\mathbf{0 . 0 3}$ & 13.12 & 8.61 & 6.85 \\
\hline $\mathrm{CD}(\mathbf{P}=\mathbf{0 . 0 5})$ & NS & 36.74 & 25.12 & 20.55 \\
\hline \multicolumn{5}{|l|}{ Sub Plots: -Sensor based irrigation schedules (S) } \\
\hline $\mathrm{S}_{1}$-Tensiometers (irrometer) & 1.05 & 424.3 & 192.7 & 132.15 \\
\hline $\begin{array}{l}\mathrm{S}_{2} \text {-Granulatedgypsum blocks (Water mark } \\
\text { sensors) }\end{array}$ & 1.22 & 468.3 & 239.2 & 184.13 \\
\hline $\mathrm{S}_{3}$-Profile probe (Delta-T) & 1.21 & 477.3 & 221.3 & 169.48 \\
\hline $\mathrm{S}_{4}-\mathrm{Nano}$ sensors (IITB) & 1.23 & 503.8 & 243.6 & 193.57 \\
\hline $\mathrm{S}_{5}$-Soil moisture indicator (ICAR) & 1.16 & 467.9 & 212.4 & 155.39 \\
\hline $\mathrm{S}_{6}$-IW/CPE ratio or Epan & 1.17 & 435.0 & 210.4 & 150.19 \\
\hline SEm \pm & 0.04 & 25.21 & 5.63 & 7.91 \\
\hline $\mathrm{CD}(\mathrm{P}=\mathbf{0 . 0 5})$ & 0.12 & NS & 16.63 & 23.33 \\
\hline \multicolumn{5}{|l|}{ Interaction } \\
\hline \multicolumn{5}{|l|}{$\mathrm{S}$ at same level of $\mathrm{M}$} \\
\hline SEm \pm & 0.06 & 35.6 & 7.9 & 11.18 \\
\hline $\mathrm{CD}(\mathrm{P}=\mathbf{0 . 0 5})$ & NS & NS & NS & NS \\
\hline \multicolumn{5}{|l|}{$\mathrm{M}$ at same or different level of $\mathrm{S}$} \\
\hline SEm \pm & 0.06 & 33.1 & 8.4 & 10.75 \\
\hline $\mathrm{CD}(\mathrm{P}=\mathbf{0 . 0 5})$ & NS & NS & NS & NS \\
\hline
\end{tabular}


Table.3 Effect of irrigation methods and irrigation schedules on grain yield, straw yield and harvest index of maize during rabi, 2017-18

\begin{tabular}{|c|c|c|c|}
\hline Treatment & $\begin{array}{l}\text { Grain yield } \\
\left(\mathrm{t} \mathrm{ha}^{-1}\right)\end{array}$ & $\begin{array}{l}\text { Straw yield } \\
\left(\mathrm{t} \mathrm{ha}^{-1}\right)\end{array}$ & $\begin{array}{l}\text { Harvest index } \\
(\%)\end{array}$ \\
\hline \multicolumn{4}{|l|}{ Main plots :Irrigation methods (M) } \\
\hline $\mathbf{M}_{1}$-Surface furrow irrigation & 5.68 & 11.16 & 33.4 \\
\hline $\mathbf{M}_{2}$-Drip irrigation & 6.30 & 12.22 & 34.2 \\
\hline SEm \pm & 0.19 & 0.35 & 0.19 \\
\hline $\mathrm{CD}(\mathbf{P}=0.05)$ & 0.61 & 1.05 & NS \\
\hline \multicolumn{4}{|c|}{ Sub Plots: -Sensor based irrigation schedules (S) } \\
\hline$S_{1}$-Tensiometers (irrometer) & 5.21 & 10.84 & 32.72 \\
\hline $\begin{array}{l}\mathbf{S}_{2} \text {-Granulated gypsum blocks } \\
\text { (Water mark sensors) }\end{array}$ & 6.76 & 12.59 & 34.92 \\
\hline$S_{3 .}$ Profile probe (Delta-T) & 5.92 & 11.23 & 33.81 \\
\hline $\mathrm{S}_{4}$-Nano sensors (IITB) & 7.05 & 12.95 & 35.43 \\
\hline 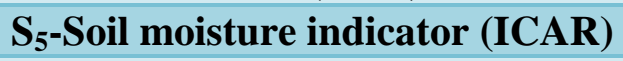 & 5.46 & 11.31 & 32.57 \\
\hline S $_{6}$-IW/CPE ratio or Epan & 5.52 & 11.23 & 32.29 \\
\hline SEm \pm & 0.13 & 0.24 & 0.73 \\
\hline $\mathrm{CD}(\mathbf{P}=\mathbf{0 . 0 5})$ & 0.38 & 0.71 & NS \\
\hline \multicolumn{4}{|c|}{ Interaction } \\
\hline \multicolumn{4}{|l|}{$S$ at same level of $M$} \\
\hline SEm \pm & 0.18 & 0.34 & 1.03 \\
\hline $\mathrm{CD}(\mathbf{P}=0.05)$ & NS & NS & NS \\
\hline \multicolumn{4}{|l|}{$M$ at same or different level of $S$} \\
\hline SEm \pm & 0.19 & 0.36 & 0.96 \\
\hline $\mathrm{CD}(\mathrm{P}=\mathbf{0 . 0 5})$ & NS & NS & NS \\
\hline
\end{tabular}

Table.4 Irrigation, total water applied, effective rainfall and water productivity influenced by irrigation methods and irrigation schedules of maize during rabi, 2017-18

\begin{tabular}{|c|c|c|c|}
\hline Treatment & $\begin{array}{l}\text { Irrigation water } \\
\text { applied (mm) }\end{array}$ & $\begin{array}{l}\text { Total water } \\
\text { applied }\left(\mathbf{m}^{3}\right)\end{array}$ & $\begin{array}{l}\text { Water Productivity } \\
\qquad\left(\mathrm{kg} \mathrm{m}^{-3}\right)\end{array}$ \\
\hline \multicolumn{4}{|l|}{ Main plots :Irrigation methods (M) } \\
\hline $\mathrm{M}_{1}$-Surface furrow irrigation & 494 & 4940 & 1.15 \\
\hline $\mathrm{M}_{2}$-Drip irrigation & 322 & 3220 & 1.96 \\
\hline \multicolumn{4}{|l|}{ Sub Plots: -Sensor based irrigation schedules (S) } \\
\hline $\mathrm{S}_{1}$-Tensiometers (irrometer) & 389 & 3890 & 1.34 \\
\hline $\begin{array}{l}\mathrm{S}_{2} \text {-Granulated gypsum blocks (Water mark } \\
\text { sensors) }\end{array}$ & 445 & 4450 & 1.52 \\
\hline $\mathrm{S}_{3}$-Profile probe (Delta-T) & 430 & 4300 & 1.38 \\
\hline $\mathrm{S}_{4}$-Nano sensors (IITB) & 460 & 4600 & 1.53 \\
\hline $\mathrm{S}_{5}$-Soil moisture indicator (ICAR) & 401 & 4010 & 1.36 \\
\hline $\mathrm{S}_{6}$-IW/CPE ratio or Epan & 366 & 3660 & 1.51 \\
\hline
\end{tabular}


This finding is similar to that of Karimi et al., (2006) who found that application of irrigation water through drip method in corn resulted in highest grain yield $\left(3899 \mathrm{~kg} \mathrm{ha}^{-1}\right)$. Ramulu et al., (2010) clearly showed that the maize crop sown under paired row with drip at $1.2 \mathrm{~m}$ spacing resulted in significantly higher yield than the conventional surface irrigation method. Similar findings were also observed by Kumar et al., (2006). Increase in grain yield under drip irrigation was mainly due to increased soil moisture status maintained in the upper $30 \mathrm{~cm}$ soil layer consequently higher plant relative water content and less negative leaf water potential (Viswanatha et al., 2002).

Significantly highest grain yield $\left(7.05 \mathrm{t} \mathrm{ha}^{-1}\right)$ was observed in nano sensor IIT-B based irrigation scheduling over rest of the irrigation schedules except gypsum block irrigation scheduling. 35.31 percent increase in grain yield was observed in nanosensor compared to the lowest treatment. This might be due to maintaining adequate soil moisture in the root zone depth throughout the crop growth period which facilitated in better uptake of water and nutrients having beneficial effect on growth viz., plant height, leaf area and LAI which favoured more production and translocation of photosynthates to the sink there by high dry matter production and yield contributing factors viz., number of cobs per plant, shelling percentage, cob weight, grain weight and test weight resulted in high grain yield. Similar findings also reported by Kumar et al., (2001), Singh (2001), Hussaini et al., (2002), Sanjeev et al., (2006), Javaid et al., (2009), Ramah et al., (2009), Shinde et al., (2009) and Hamidreza et al., (2011). Whereas the grain yield realised with gypsum block (6.76 t $\mathrm{ha}^{-1}$ ) based irrigation schedule was on par with yield obtained with nano sensor. The lowest grain yield $\left(5.21 \mathrm{t} \mathrm{ha}^{-1}\right)$ obtained by tensiometer based irrigation scheduling. Reddy et al., (2002) observed higher sugar beet yield $\left(95 \mathrm{t} \mathrm{ha}^{-1}\right)$ when irrigation was scheduled based on watermark sensors (gypsum block) along with saving of $18 \%$ water when compared to farmers practice. Chen et al., (2009) and Simon et al., (2013) concluded that the maize grain yield reduced with decreasing irrigation amounts and the maximum grain yield was obtained under fully irrigated treatment. The grain yield of maize was not significantly influenced by the interaction effect of irrigation methods and irrigation schedules.

\section{Straw yield $\left(\mathrm{tha}^{-1}\right)$}

Perusal of data indicates that straw yield of maize was significantly influenced by irrigation methods and irrigation schedules. Drip irrigated plots showed significantly higher straw yield $\left(12.22 \mathrm{t} \mathrm{ha}^{-1}\right)$ when compared to surface irrigated plot (11.16 $\mathrm{t} \mathrm{ha}^{-1}$ ) (Table 3). This might be due to better vegetative growth, more dry matter production and biological yield produced under favoured soil moisture availability in drip irrigated plots (Sanjeev et al., 2006). Irrigation schedules significantly influenced the straw yield. The highest straw yield (12.95 $\mathrm{t} \mathrm{ha}^{-1}$ ) was observed in nano sensors IIT-B based irrigation scheduling closely followed by gypsum block $\left(12.59 \mathrm{t} \mathrm{ha}^{-1}\right)$ and differed significantly over rest of the schedule studied. Whereas, the lowest straw yield $\left(10.84 \mathrm{t} \mathrm{ha}^{-1}\right)$ obtained by tensiometer based irrigation scheduling might be due to low leaf area index, leaf area and dry matter production which ultimately lead to lower straw yield (Qadir et al., 1999). 19.46 percent increase in straw yield was observed in nano sensor compared to the lowest treatment. The straw yield was not significantly influenced by the interaction effect of irrigation methods and irrigation schedules.

\section{Harvest index (\%)}

The harvest index of maize was not significantly influenced by irrigation methods 
and irrigation schedules. However, relatively high harvest index was observed in drip irrigated plot (34.2) compared to surface irrigated plot (33.4) (Table 3). Increasing moisture stress resulted in progressively less harvest index (Pandey et al., 2000). Relatively high harvest index (35.43) was observed in nano sensor based irrigation scheduling followed by gypsum block (34.92), profile probe (33.81), soil moisture indicator (32.57), IW/CPE ratio (32.29) and lowest (32.72) was with tensiometer based irrigation scheduling. The harvest index was not significantly influenced by the interaction effect of irrigation methods and irrigation schedules. Payero et al., (2008) recorded as low as $28 \%$ harvest index when plants are subjected to water stress after tasseling and maximum harvest index $(61.77 \%)$ was obtained with fully irrigated treatment. Karam et al., (2003) revealed that water plays an important role in partitioning of the dry matter and application of optimum quantity of water results in better $\mathrm{HI}$ in maize crop.

\section{Water use studies}

The data pertaining to amount of applied water on rabi maize was presented in table 4 The amount of total water applied under drip irrigation was $322 \mathrm{~mm}$ against the surface irrigation of $494 \mathrm{~mm}$. The percent applied water saving in drip irrigation was $35 \%$, over surface furrow irrigation. This result is in line with the findings of Anitha and Muthukrishnan (2011) that reduction in water consumption due to drip method of irrigation over the surface method of irrigation varied between 30 to 70 per cent and productivity gain in the range of 20 to $90 \%$ for different crops. It might be due to effective utilization of water by crop in drip system as compared to conventional surface irrigation methods. Whereas, in sensor based irrigation scheduling an amount of 389, 445, 430, 460, 401 and $366 \mathrm{~mm}$ was used by tensiometer, gypsum block, profile probe, nano sensor (IIT-B), soil moisture indicator and IW/CPE ratio respectively. Rainfall received during the crop growth period was nil.

\section{Water productivity (WP)}

A scrutiny of the data reveals that among irrigation methods, the drip irrigation recorded relatively higher WP $\left(1.96 \mathrm{~kg} \mathrm{~m}^{-3}\right)$ over surface furrow irrigated plots (1.15 $\mathrm{kg} \mathrm{m}^{-3}$ ) (Table 4). Water productivity was three times more under drip irrigation than the furrow irrigation (Kadasiddappa et al., 2015). The highest water productivity in drip irrigated treatments could be due to higher grain yield obtained coupled with lower water requirement (Fanish et al., 2011). Similar results were reported by Kumar et al., (2006) in cotton. Highest water productivity was associated with nano sensor (IITB) and gypsum block based irrigation schedules $\left(1.53,1.52 \mathrm{~kg} \mathrm{~m}^{-3}\right.$ respectively)

It may be concluded that the amount of total water applied under drip irrigation was 322 $\mathrm{mm}$ against the surface furrow irrigation of $494 \mathrm{~mm}$. Drip irrigation shown comparatively higher water productivity $\left(1.96 \mathrm{~kg} \mathrm{~m}^{-3}\right)$ compared to surface furrow irrigation (1.15 $\mathrm{kg} \mathrm{m}^{-3}$ ) and among the schedules higher water productivity (1.53) was associated with nano sensor (IITB). Simultaneously, nano sensor (IITB) based irrigation system enhanced the highest grains per plant (184.13 g), cob weight per plant (243.65 g) and grain yield $\left(7.05 \mathrm{t} \mathrm{ha}^{-1}\right)$ of maize.

\section{References}

Anitha, F.S and Muthukrishnan, P. 2011. Effect of drip fertigation and intercropping on growth, yield and water use efficiency of maize (Zea mays L). Madras Agriculture Journal. 98 (79): 238-242. 
Asim, O.E and Abdelmoniem, E.M. 2011. Irrigation scheduling for maize (Zea mays L.) under desert area conditionsnorth of Sudan. Agriculture and Biology Journal of North America. 4: 645-651.

Aulakh, G.S., Vashist, K.K., Sharma, S and Mahal, S.S. 2012. Productivity, quality and water expense efficiency of late kharif sown hybrid maize (Zea mays L.) under different irrigation regimes and nitrogen levels. Journal of Crop and Weed. 8 (2): 139-142.

Cakir, R. 2004. Effect of water stress at different development stages on vegetative and reproductive growth of corn. Field Crops Research. 89 (1): 116.

Chen, C., Wang, E and Yu, Q. 2009. Modelling the effects of climate variability and water management on crop water productivity and water balance in the North China Plain. Agricultural Water Management. 10: 212-222.

Fanish, S.A., Muthukrishnan, $\mathrm{P}$ and Manoharan, S. 2011. Effect of drip fertigation in maize (Zea mays L.) based intercropping system. Indian Journal of Agricultural Research. 45 (3): 233-238.

Gardner, W.H. Water content. In Methods of Soil Analysis, Part 1. Physical and Mineralogical Methods, 2nd ed.; Arnold Klute: Madison, WI, USA, 1986; pp. 493-544.

Gomez, K.A. and Gomez, A.A. 1984. Statistical Procedures for Agricultural Research. John Wiley and Sons, 639p.

Hamidreza, S., Mohd, A.M.S., Teang, S.L., Mohd, K.Y and Desa, A. 2011. Effect of deficit irrigation on water productivity and maize (Zea mays L.) yield in arid regions of Iran. Pertanika Journal of Tropical Agriculture Sciences. 34 (2): 207-216.

Hussaini, M. A., Ogunlela, V. B., Ramalan,
A. A., Falaki, A. M and Lalwal, A. B. 2002. Productivity and water use in maize (Zea mays L.) as influenced by nitrogen, phosphorus and irrigation levels. Crop Research. 23 (20): 228234.

Javaid, A., Tariq and Usman, K. 2009. Regulated deficit irrigation scheduling of maize crop (Zea mays L.). Sarhad Journal of Agriculture. 25 (30): 441450.

Kijne, J.W., Barker, R., Molden, D., 2003. Water Productivity in Agriculture: Limits and Opportunities for Improvement. $\mathrm{CAB}$ International, Wallingford, UK.

Kumar, M., Tripathi, R.S and Shrivastava, G.K. 2001. Quality and yield of winter maize (Zea mays L.) as affected by varying genotypes, nitrogen levels and irrigation schedules. Madras Agricultural Journal. 88 (10-12): 693696.

Kumar, T., Krishnasamy, S., Ramesh, K and Shanmugasundaram, K. 2006. Effect of drip and surface irrigation methods with rice straw mulch on productivity andwater use efficiency of summer cotton. Crop Research. 32 (2): 141-144.

Mohamed, S.A.E.M., Fawzi, S.M and Hussein, M.A.G. 2011. Evaluation of soil moisture sensors under intelligent irrigation systems for economical crops in arid regions. American Journal of Agricultural and Biological Sciences. 6 (2): 287-300.

Pandey, R.K., Maranville, J.W and Admou, A. 2000. Deficit irrigation and nitrogen effects on maize in a Sahelian environment grain yield and yield components. Agricultural Water Management. 46: 1-13.

Payero, J.O., David, D., Tarkalson, Suat Irmak, Don Davison, James, L and Petersen. 2008. Effect of irrigation amounts applied with subsurface drip 
irrigation on corn evapotranspiration, yield, water use efficiency and dry matter production in Semi arid climate. Agricultural Water Management. 95 (8): 895-908.

Qadir, G., Saeed, M and Cheema. 1999. Effect of water stress on growth and yield performance of four wheat cultivars. Pakistan Journal of Biological Sciences. 1: 236-239.

Ramah, K., Santhi, P and Ponnuswamy, K. 2009. Irrigation scheduling and water use efficiency in maize (Zea mays L.) based cropping system under drip irrigation. Crop Research. 38: 15-20.

Ramulu, V., Reddy, M.D and Rao, A.M. 2010. Response of rabi maize to irrigation schedules and fertigation levels. Agricultural Science Digest. 30 (2): 104-106.

Reddy, S., Neufeld, J., Gallian, J., Neibling, H., Ellsworth, J and Gortsema, S. 2002. Sugarbeet irrigation management using watermark moisture sensors. University of Idho Extension, Idho Agricultural Experiment Station.

Salah, E., El-Hendaway., Abd El-lattief, E.A., Mohamed, S., Ahmed and Schmidhalter, U. 2008. Irrigation rate and plant density effects on yield and water use efficiency of drip-irrigated corn. Agricultural Water Management. 95: 836-844.

Sanjeev, K., Mishra, S and Singh, V.P. 2006. Effect of tillage and irrigation on soil water plant relationship and productivity of winter maize (Zea mays
L.) in north Bihar. Indian Journal of Agricultural Science. 76 (9): 526-530.

Setter, T., Flannigan, B.A and Melkonian. J. 2001. Loss of kernel set due to water deficit and shade in maize: carbohydrate supplies, abscisic acid, and cytokinins. Journal of Crop Science. 41(5): 15301540.

Shah, N.G. and Das, I. 2012. Precision irrigation sensor network based irrigation, problems, perspectives and challenges of agricultural water management", IIT Bombay, India, pp. 217-232.

Sharan, B. 2012. Performance of sweet corn hybrid under different levels of irrigation and nitrogen applied through drip system. M.Sc. (Ag.) thesis submitted to ANGRAU, Hyderabad.

Shinde, S.A., Shelke, D.K and Sawargoankar, G.L. 2009. Effect of irrigation schedules and integrated nutrient management on yield and nutrient uptake of rabi maize (Zea mays L.). International Journal of Plant Sciences. 4 (1): 24-26.

Simon, J., Van, D., James, L.P and Davison, D.R. 2013. Effect of amount and timing of subsurface drip irrigation on corn yield. Irrigation Sciences. 3: 599-609.

Viswanatha, G.B., Ramachandrappa, B.K and Nanjappa, H.V. 2002. Soil plant water status and yield of sweet corn (Zea mays L. cv. Saccharata) as influenced by drip irrigation and planting methods. Agricultural Water Management. 55: 85-91.

\section{How to cite this article:}

Durga, C., V. Ramulu, M. Umadevi and Suresh, K. 2020. Evaluation of Effectiveness of Nano Sensor (IITB) Based Irrigation System on Water Productivity and Yield of Maize (Zea mays). Int.J.Curr.Microbiol.App.Sci. 9(08): 2697-2706. doi: https://doi.org/10.20546/ijcmas.2020.908.306 